На думку розробників програми вона дозволить [20]:

- грунтовно ознайомитися 3 історією християнства та богословською проблематикою в іï теоретичних і практичних аспектах, особливо що стосується співвідношення церкви 3 державою та суспільством;

- осягнути місце і роль християнства в історії та культурі;

- глибше зрозуміти сутність сучасних релігійних процесів в Україні та світі в громадсько-політичному контексті (у трикутнику «церква-суспільство-держава»);

- ознайомитися 3 тенденціями розвитку сучасного релігійного життя і богословської думки та їх впливом на громадсько-політичні процеси.

\title{
Посилання
}

1. https://www.academia.edu/8201921/Засади_політичної_теології_в_украї нському_контексті

2. https://en.wikipedia.org/wiki/Carl_Schmitt

3. Шмитт К. Политическая теология. - М:. Канон-Пресс-Ц, 2000.

4. https://en.wikipedia.org/wiki/J\%C3\%BCrgen_Moltmann

5. http://orthodox.org.ua/article/protokol-№2-zasidannya-soboru-€piskopivukraïnskoï-pravoslavnoï-tserkvi-1

6. https://www.facebook.com/kovalenkogeorge/posts/831367726895731

7. https://en.wikipedia.org/wiki/Reinhold_Niebuhr

8. https://en.wikipedia.org/wiki/John_Courtney_Murray

9. http://en.wikipedia.org/wiki/Max_Lynn_Stackhouse

10.http://www.ptsem.edu/library/kuyper/

11.http://en.wikipedia.org/wiki/Richard_John_Neuhaus

12.http://www.firstthings.com/

13.http://www.csu.edu.au/gnpt/home

14.http://www.csu.edu.au/research/pact

15.http://www.brill.com/international-journal-public-theology

16.http://www.csu.edu.au/faculty/arts/theology/pact

17.http://www.radiosvoboda.org/content/article/25201404.html

18.https://www.facebook.com/kovalenkogeorgiy/posts/513210395443600

19.https://www.youtube.com/watch?v=7eL9eNUaPK0

20.http://www.ukma.edu.ua/images/docs/science/teologiya.pdf

Андрій Юраш (Київ)

ДРУГИЙ ВАТИКАНСЬКИЙ СОБОР ЯК ВИКЛИК І СПОНУКА ДЛЯ РОЗВИТКУ БОГОСЛОВСЬКО-ЕКЛЕЗІОЛОГІЧНОЇ ТРАДИЦЇ̈ ХРИСТИЯНСЬКОГО СХОДУ

У статті розглядаються довготривалий прочес та заходи з інтенсифікації загальноправославних зусиль упродовж $X X \mathrm{~cm} . \quad 3$ 
підготовки Вселенського Всеправославного Собору, які набули особливої динаміки після II Ватиканського Собору (1962-1965 рр.).

Ключові слова: Вселенський Православний Собор, православні передсоборні наради, Православні Церкви, Константинопольський nатріархат, Московський патріархат.

Andriy Yurush

\section{THE SECOND VATICAN COUNCIL AS A CHALLENGE AND MOTIVATION FOR DEVELOPMENT OF THE OLOGICAL- ECCLESIOLOGICAL TRADITION OF THE CHRISTIAN EAST}

The article deals with long-term process and measures to intensify the all orthodox efforts during the twentieth century for the preparation of the Ecumenical Orthodox council, which acquired the special dynamics after the Second Vatican Council (1962-1965).

Keywords: Ecumenical Orthodox Council, Orthodox precouncil meetings, Orthodox Churches, Constantynopol Patriarchate, the Moscow Patriarchate.

Офіційне повідомлення для якнайширшої громадськості про потребу і можливість скликання II Ватиканського Собору було зроблене у Римі 17 травня 1959 року, тобто більш як за три роки до відкриття першої сесії Собору, яка розпочала роботу 11 жовтня 1962 року. Свідченням того, що ці передсоборові очікування, дискусії, приготування, зокрема оголошення у Ватикані 5 червня 1960 року про створення Центральної підготовчої комісії і 10 робочих комісій, дістали якнайжвавіший відголос у православному середовищі $\epsilon$ факт скликання у період 3 24-го по 30-е вересня 1961 року на о. Родос Першої Всеправославної наради представників Помісних Православних Церков. При цьому завдання, яке було поставлене перед представниками Православних Церков, виглядало не менш глобальним i масштабним, аніж завдання, що його вже вирішували на той час католицькі ієрархи і богослови у рамках підготовки Вселенського Собору Західної Церкви: вироблення програми і розробка практичних заходів з організації нового Восьмого Вселенського собору Східної Православної Церкви.

Очевидної взаємозалежності цих двох подій, навіть певного хронологічного паралелізму між ними не помітити досить тяжко. Беззаперечним і абсолютно очевидним фактом $є$ те, що повідомлення 3 Ватикану $з$ перших же місяців понтифікату Іоанна XXIII про майбутнє скликання всезагального собору Західної Церкви спонукали спільноту Православних Церков максимально пришвидшити власні зусилля щодо пошуку об'єднавчих ідей та зреалізування давнього плану скликання чергового вселенського собору, якого Православна Церква не знала 
майже 1200 років, від 787 року, себто дати проведення Сьомого Вселенського Собору.

Важливо відзначити, що, говорячи про інтенсифікацію загальноправославних зусиль щодо підготовки омріяного нового Вселенського (у конкретних обставинах XX сторіччя - Всеправославного) Собору під очевидним впливом започаткованих на рубежі $50-60$-х років організаційних зусиль щодо скликання Собору Західної Церкви, не можна не згадати унікально цікавої та контраверсійної передісторії цього явища. При цьому відразу слід відзначити одну принципово важливу тенденцію: якщо у післявоєнний час констатовані нами зусилля Православних Церков щодо підготовки Вселенського Собору були інтенсифіковані під впливом новин, які почали надходити з Ватикану, то в міжвоєнний час соборницькі інтенції вселенського масштабу в ойкумені Православних Церков були самостійним, оригінальним і навіть унікальним явищем, яке на кілька десятиріч випереджувало ту модерністську ідеологію, яка у Католицькій Церкві почала домінувати лише у часах понтифікату життерадісного папи-антиформаліста Іоанна XXIII.

Отож, міркуючи про чотири Всеправославні наради, що у 1960-х рр. відбувалися на о. Родос $(1961,1963$ і 1964) та у Шамбезі, що поблизу Женеви (1968), про діяльність Міжправославної підготовчої комісії, яка працювала у першій половині $1970-\mathrm{x}$ років, і проведення Чотирьох Всеправославних передсоборних нарад, організованих у Шамбезі (1976, 1982, 1986 i 2009) для вироблення порядку денного майбутнього Всеправославного Собору, слід обов'язково згадати паралельно з цими доволі добре відомими сторінками новітньої історії Православ'я ще й події, про які мало хто пам'ятає, але які переконують у перманентній присутності у богословській практиці Православ'я, у XX сторіччі зокрема, ідеї зорганізування, як це офіційно прозвучало у документах передсоборових зустрічей, Святого і Великого Собору Східної Православної Церкви.

3 одного боку, в еклезіологічній свідомості Православної Церкви завжди були присутні елементи чи компоненти, які свідчать про іiі замкнутість і самоцільну історичну довершеність, себто очевидною була i залишається свідома відмова від націленості на творчий розвиток i вдосконалення. Іншими словами, «охоронний» комплекс «вартового незмінної істини» очевидно домінує над комплексом «невтомного будівничого», що прагне удосконалювати і перебудовувати духовний «храм» віри. Серед найяскравіших проявів цієї тенденції можна згадати почуття винятковості, що притаманне багатьом носіям православної ідентичності, комплекси обраності, погорди, недовіри і навіть зверхності до інших, а також - месіанства, тобто покликаності зберегти у незмінному, «чистому» вигляді свято-отцівську віру, затверджену на Семи Вселенських соборах. 
Але з іншого боку, якщо не у більшості, то, принаймні, у значної частини мислячої богословської еліти Православних Церков завжди був присутній і в певний просіб виявляв себе і цілком протилежний комплекс - підсвідоме відчуття потреби задекларувати і підтвердити збережену, але за більш як тисячоліття заформалізовану віру і літургійний обряд у рамках нового спільного для всіх Православних Церков соборного зібрання, яке б єдине, згідно 3 соборницькою схемою мислення, властивою для всіх православних, дало легітимну відповідь на численні запитання, що накопичились за сотні років існування без творчої інтервенції у догматичну і літургічну церковну практику. Оскільки саме посиланням на авторитет Семи Вселенських соборів православні завжди обгрунтовували всі свої відмови від модернізму будь-якого роду і в будьяких сенсах, то, власне, зорганізований i проведений за участі всіх Православних Церков новий Всеправославний Собор, згідно логіки апологетів цього напряму мислення, зможе створити легітимний, тобто канонічний грунт для тих реформ, на які так давно очікує і яких потребує Православ'я. Таким чином, констатований вище тиск «соборницької» свідомості породжує чи супроводжує явища цілком протилежного змісту: з одного боку, консерватизм і відрубність на межі з маргінальністю, а 3 іншого боку - націленість на пошук шляхів модернізації, оптимізації і знаходження адекватного місця у християнському світі.

I, власне, під тиском саме цього відчуття - тривалого браку соборного самовираження - за перших же сприятливих умов підсвідоме чи, навпаки, усвідомлене прагнення до соборової творчості дало про себе знати. Майже відразу після завершення катаклізмів Першої світової війни, політичного, a, в певному сенсі, й часткового культурного переформатування Європи і навіть цілого світу (згадаймо хоча б розпад кількох імперій), утвердження і просування численних ліберальних та модернізаційних концептів, активування у практичній площині відверто богоборчої, атеїстичної держави (Радянський Союз), себто коли церковна свідомість, яка протягом кількох попередніх не просто десятиліть, але навіть сторіч була пригальмована відносною стабільністю існуючих цивілізаційних і політичних систем, у часі війн та революцій набралася певної відваги і рішучості, почали й у православному середовищі виникати сміливі ідеї та відповідні організаційні потуги щодо їх зреалізування. Ці ідеї передбачали втілення назрілих церковних реформ у рамках ініціювання та скликання Всеправославного собору за участі представників усіх помісних, що існували на той час (Польська, Албанська, Чеська і в Словацьких землях автокефальні Православні Церкви у той час ще не були уконституйовані), Православних Церков.

Ведучи мову про сприятливу для модернізаційних зрушень атмосферу, маємо на увазі початок 1920-х років. Власне тоді, 3 лютого 1923 року Константинопольський патріарх Мелетій IV (Метаксакис) звернувся до предстоятелів усіх православних Церков із 
закликом надіслати своїх представників для започаткування роботи спеціальної загальноправославної комісії, що мала б розглянути актуальні для тогочасного Православ'я питання та вказати, як було сказано у документі, «шляхи їхнього канонічного вирішення» [1]. Вже через кілька місяців, 10 травня 1923 року ініційоване патріархом Мелетієм зібрання, що первісно мало назву «Комісія Православних Церков», розпочало свою роботу і у формі 11 засідань тривало до 8 червня (майже місяць). Під тиском констатованої нами вище пан-православної соборницької свідомості на 3-му засіданні члени комісії, зібраної у Константинополі, прийняли рішення про перейменування зустрічі у «Всеправославний конгрес». I це при тому, що навіть з 9-ти Православних Церков, які у той час перебували у євхаристійному спілкуванні, тільки 5 брали участь у зібранні на рівні повноважних представників - Константинопольська, Сербська i Румунська патріархї̈, а також Елладська та Кіпрська архієпископії. При цьому Александрійська, Антіохійська та Єрусалимська Церкви через внутрішні складності відмовилися від участі у зібранні, Болгарська і Грузинська Церкви ще не були визнані Константинополем i тому не були залучені до участі у Конгресі, а через зрозумілі проблеми i конфлікти 3 радянською владою офіційні представники Московської патріархії не могли прибути на нараду.

Щоправда, початково у роботі зібрання брали участь два російські ієрархи із числа тих, хто залишив більшовицьку Росію і здійснював свою місію закордоном - архієпископи Кишинівський і Хотинський Анастасій (Грібановскій) та Алеутський i Північноамериканський Алєксандр (Нємоловскій). Однак це представництво Російського Православ'я не може бути визнане за повносиле не тільки через те, що згадані ієрархи не мали жодних офіційних повноважень (ні від Патріаршого Синоду у Москві, ні від Архієрейського Синоду РПЦ закордоном), але й тому, що через незгоду із новаторсько-модерністичним духом зібрання вони доволі швидко залишили Конгрес.

Міркуючи про це зібрання, яке відкривало цілу галерею організаційних потуг Світового Православ'я щодо проведення представницького загальноцерковного собору, найбільш вражаючим є не сам факт ініціювання та проведення Конгресу, а його первісна націленість на обговорення настільки серйозних і складних проблем, що до їхнього вирішення, за одним частковим і несистемним винятком, Православна Церква й до сьогодні, ледь не сто років потому, не може приступити.

Говорячи про виняток, маємо на увазі т.зв. «календарне питання», якому було цілком присвячено перші чотири засідання Конгресу. Розглядаючи цю тему та кілька варіантів модернізації староюліанської пасхалії, учасники прийшли до думки не лише про доречність переходу на новий, григоріанський календар, але й (!!!) щодо можливості фіксованого святкування Пасхи спільно з Католицькою Церквою в одну з визначених неділь квітня. Відразу ж на базі рішень Конгресу новий стиль 
прийняли Константинопольська, Румунська та Елладська Церкви. Пізніше відповідне рішення було підтримане Церквами Александрії, Антіохії, Болгарії, Кіпру, Албанії, Польщі та Чехії і Словацьких Земель. Прийнявши новий стиль в цілому (святкування за ним річного циклу свят), жодна 3 названих вище церков (за винятком Фінляндської автономної Церкви, що перебуває в юрисдикції Константинопольського патріархату) не наважилась перейти й на григоріанську пасхалію (святкування й Пасхи за новим стилем), таким чином втіливши рішення Константинопольського Конгресу 1923 року лише частково.

Інші ж його радикально-модерністичні визначення, які були запропоновані Світовому Православ'ю на хвилі ентузіазму та за підтримки прогресивного і схильного до нововведень патріарха Мелетія, так і залишились у площині рекомендацій. Малочисельні i a пріорі реформаційно налаштовані учасники Конгресу не змогли вплинути на суттєво консервативніші спільноти своїх Церков, аби імплементувати інші напрацювання Конгресу. Назвемо лише окремі 3 них: можливість шлюбу ієреїв та дияконів після прийняття таїнства священства, беручи до уваги автономність двох таїнств; допустимість другого шлюбу для овдовілих священиків та дияконів; встановлення обов'язкових нижніх вікових меж при здійсненні дияконських, священичих та архієрейських рукоположень (відповідно, 21, 24 і 30 років); дозвіл на гоління волосся i борід священнослужителями, носіння ними світського одягу поза межами храмів (близько ста років тому це було надзвичайно важливим нововеденням); скорочення кількості і послаблення постів; перенесення церковних свят, у першу чергу днів пошанування святих у відповідних церковних традиціях, що випадають у будні дні, на найближчі неділі; загальне скорочення тривалості богослужінь; розширення переліку підстав для церковних розлучень тощо. Окремо було задекларовано i заявлено про можливість і необхідність зближення із Католицькою та Англіканською Церквами.

Оптимізм та віра «конгресових» отців і світських його учасників у швидке здійснення їхніх реформаційних задумів проявилася ще й тому, що для загальноцерковного затвердження та підтримки їхніх планів було визначено вже через два роки, себто 1925-го року, скликати Всеправославний Вселенський Собор. Вага і значення цього Собору для долі Церкви, за задумом його ініціаторів, мали б бути настільки ж визначальними, як і рішень Першого Вселенського Собору, святкування 1600-ї річниці якого мали відбутися того 1925 року.

Після закриття Конгресу i предметного обговорення його результатів у Помісних Церквах, а також листовного з'ясування деталей майбутнього Собору предстоятелями чи їхніми повноважними представниками консенсусно було вирішено зробити паузу, утворити спеціальну комісію та скликати т.зв. Передсобор із представників Помісних Церков для узгодження і підготовки документів, призначених 
для затвердження на майбутньому Всеправославному соборі. Як наслідок, гальмування темпів зреалізування передсоборного процесу призвело до того, що будь-які серйозні наміри щодо проведення Вселенського собору 1925 року були розлагоджені. Результати Константинопольського Всеправославного Конгресу майже у всіх визначеннях та документах Помісних Церков були скритиковані, поставлені під сумнів та затавровані як такі, що були продиктовані революційно-модерністськими обставинами перших післявоєнних років.

Щоправда, в принципі робота над втіленням у життя ідеї організації загальноправославного Вселенського Собору не була зупинена. Результати і наслідки семирічного обговорення концепту Собору були підведені у 1930-му році, коли 8-23 червня представники 9 Помісних Церков зібралися у Ватопедському монастирі на Афоні у рамках т.зв. Міжправославної підготовчої комісії Передсобору [2]. На цьому зібранні було визначено 32 теми, що могли б стати головними у рамках підготовки та скликання майбутнього Всеправославного зібрання. У рамках 15-денних дискусій було вирішено рівно у два рази зменшити кількість тем, що мали б стати предметом обговорень на майбутньому Соборі, а скликання самого Передсобору було призначено на 1932 рік у тому ж Ватопедському монастирі.

Російська т.зв. патріарша Церква у роботі Ватопедського зібрання участі не брала, оскільки іiі предстоятель, місцеблюститель патріаршого престолу Митрополит Ніжегородський Сєргій образився на Вселенську патріархію за те, що від ії імені запрошення було направлене не лише для нього, але й для глави досить впливової у той час Живої (Обновленської) Церкви - митрополита Московського Вєніаміна (Муратовского). Традиційно Російське Православ'я категорично унеможливлює свою співпрацю у рамках будь-яких ініціатив, де беруть участь також ії прямі та непрямі організаційні опоненти. Щоправда, якщо відвертий шантаж i очевидна категоричність Московської Патріархії не спрацьовували у першій половині XX сторіччя, то післявоєнні й сучасні обставини переконують у суттєво більшій успішності цієї тактики і відповідної лінії поведінки, у стосунках з Ватиканом і Вселенським патріархатом у тому числі.

Роз'єднаність Православних Церков і відсутність серед церковних спільнот та ієрархії чіткого та однозначного бачення пріоритетів та реформаційних завдань призвели до того, що не відбулося не тільки призначеного на 1925 рік Всеправославного Собору, але й визначеного на 1932 рік Передсобору. Більш як на тридцять років будь-яка активність Православних Церков у відповідному напрямі де-факто була загальмована (єдиним, але не вирішальним винятком можна вважати проведення 1936 року Першої всеправославної конференції православних богословів в Афінах 1936 року), а відновилася вона лише на рубежі 1950-1960-х під впливом, як вже було відзначено вище, повідомлень із Ватикану про 
унікальну ініціативу Папи Іоана XXIII щодо скликання загального собору ієрархії Західної Церкви.

Отож, порівнюючи активність та націленість Католицької i Православної Церков щодо відновлення у XX сторіччі власної соборової діяльності найвищого загальноцерковного організаційного рівня, слід відзначити щонайменше дві очевидні тенденції та відповідні факти, які доводять слушність обох трендів. По-перше, однозначно, що ідея та організаційний рух, що мав на меті скликання новітнього Вселенського Собору, швидше виникли (щонайменше, коли говорити про серйозний організаційний рівень, а не лише про інтелектуальні дискусії) у рамках Світового Православ'я, маючи у своїй передоснові відносно прогресивний Помісний собор Російської Церкви 1917-18 років та радикально-реформістські настрої у Константинопольській Патріархії, що дістали навіть відоме організаційне довершення і сприяння 3 боку ліберально налаштованого Екуменічного патріарха Мелетія IV. Але одночасно слід відзначити й іншу тенденцію: хронологічно більш ранні ініціативи Православних Церков були драматично неуспішними, несистемними,організаційно недовершеними,в той час як відповідний концепт у Католицизмі за безпосереднього протегування з боку папи Іоана XXIII та відомої організаційної чіткості і адміністративної відповідальності католицької ієрархії, чиї зусилля вдало координували ватиканські куріальні інституції, був доведений до відомого логічного рішення винятково швидко і переконливо успішно.

Але повернемося до вже кілька разів згаданих нами спроб православної світової спільноти щодо проведення попередніх зібрань, які мали б підготувати Вселенський чи Всеправославний або, як його називають у т.зв. «грецькому» світі, Пан-православний собор. Дізнавшись про папську ініціативу, Константинопольський патріарх Афінагор (Атенагор) відразу ж згадав про результати зібрання 1930-го року у Ватопедському монастирі, який визначив 16 пунктів як теми для першочергового обговорення на майбутньому всеправославному зібранні. Власне, ці 16 проблем і стали предметом обговорення на I Родоській Загальноправославній Нараді (1961 рік). Як результат обговорення цих тем на зустрічі на о. Родос делегати сформували ще більш широкий каталог проблем, які хвилювали в той час Світове Православ'я i потребували вирішення на загальноцерковному рівні. Усі ці теми були систематизовані за 8-ма розділами і запропоновані для всіх Церков для більш широкого розмірковування і застановлення. Фактично, ці 8 розділів (1. Віра і догмат; 2. Богослужіння; 3. Управління і церковний устрій; 4. Взаємостосунки між Православними Церквами; 5. Взаємостосунки Православної Церкви з рештою християнського світу; 6. Православ'я у світі; 7. Загальнобогословські теми; 8. Соціальні проблеми) і мали стати темами, що потребували б їхнього розгляду і вирішення на новітньому Вселенському Соборі. 
Започаткована 1961-го року праця була продовжена на двох наступних Нарадах на о. Родос 1963-го і 1964-го років та на останній IV-й Нараді у 1968-му році у містечку Шамбезі, що поблизу Женеви у представництві Екуменічного (Вселенського) Патріархату. Власне, на цій Нараді було обговорено та запропоновано процедуру підготовки Вселенського Собору Православної Церкви, якому, згідно з новою концепцією, мав передувати не Передсобор, як зазначалося у документах Ватопедського зібрання 1930 року, а серія Всеправославних пересоборних нарад та робота Міжправославних комісій 3 підготовки Собору. Для координації зусиль було засновано Секретаріат зі штаб-квартирою у вже згаданому Шамбезі.

Згідно 3 цими рішеннями, 3 різною періодичністю до сьогоднішнього дня відбулося чотири Загальноправославні передсоборні наради у Шамбезі - 1976-го, 1982-го, 1986-го років і зовсім нещодавня 2009-го року. Вже на першій Нараді було оновлено перелік тем, що потребують першочергової уваги світової православної спільноти. Очікувано чільні позиції серед пріоритетних проблем зайняли питання формалістично-організаційні в еклезіологічній площині - зовнішнього влаштування та гармонізації стосунків усередині Світового Православ'я (Православної ойкумени): православна діаспора, автокефалія і способи іiі проголошення, автономія та способи іiі проголошення, диптихи, себто порядок поминання предстоятелів Церков. Окрім того, у центр уваги потрапили ще 6 проблем: спільний календар, перешкоди для шлюбу, церковні настанови про піст, ставлення до решти християнського світу, екуменічний рух та питання участі Православних Церков у боротьбі за мир та окремі соціальні питання.

У цьому контексті немає сенсу розглядати у деталях характер перебігу такої тривалої передсоборової активності у світовому православ'ї. Важливіше відзначити інше: відсутність об'єднавчого центру, який би користувався беззаперечним авторитетом для всіх православних Церков і чіткіше координував та більш рішуче спрямовував зусилля задля зреалізування стратегічної мети, призвела до такого порядку речей, при якому майже дев'яносторічні практичні спроби Православних Церков зібрати черговий Вселенський собор не змогли набути хоч якихось реальних обрисів.

Ситуація усередині світового православ'я натомість була i залишається ускладненою не тільки суттєво серйознішими $\mathrm{i}$ навіть зростаючими в окремих Церквах фундаменталістськими настроями, але й очевидним протистоянням на всіх рівнях та з різних приводів між двома чільними, ідеологічно та організаційно знаковими Церквами-лідерами (Константинопольським і Московським патріархатами), що паралельно і часто не узгоджено поміж собою демонструють об'єктивні інтенції і організаційні потуги у сенсі скликання Вселенського Православного Собору. У реальності ж ці організаційні зусиллі двох церковних центрів 
не лише не гармонізовані, але й виглядають як такі, що часто цілком 3 протилежних позицій прагнуть вибудовувати концепції вирішення i ставлення до питань, що мали б бути поставлені і вирішені у рамках «соборного» процесу.

\section{Олена Данилюк (Житомир)}

\section{ОСОБЛИВОСТІ ЄВАНГЕЛІЗАЦІЙНО-МІСІОНЕРСЬКОЇ ДІЯЛЬНОСТІ РИМО-КАТОЛИЦЬКИХ ЧЕРНЕЧИХ ОРДЕНІВ У КИЄВО-ЖИТОМИРСЬКІЙ ДІЄЦЕЗІЇ}

Розглядається діяльність римо-католицьких чернечих орденів на теренах Києво-Житомирської дієцезї в сучасних умовах розбудови української державності.

Ключові слова: Римо-католицька Церква, дієцезія, чернечі ордени.

Olena Danyliuk

\section{FEATURES EVANGELISTIC AND MISSIONARY ACTIVITIES OF ROMAN CATHOLIC RELIGIOUS ORDERS IN KYIV-ZHYTOMYR DIOCESE}

The article deals with the activities of of Roman Catholic Religious Orders in the territory of Kyiv-Zhytomyr Diocese, their role and place on contemporary conditions of Ukrainian state.

Keywords: Roman Catholic Church, Diocese of the Roman Catholic Church, Roman Catholic Religious Orders.

Чернече життя $\epsilon$ багатогранним явищем, насамперед, - це поширена в ряді релігій форма реалізації ідеалу праведного життя [1, с. 376]. Чернецтво зароджувалося як свого роду контркультура, що протиставила себе суспільству і нормативному християнству та стало складним i незалежним рухом у лоні Католицької церкви [2, с. 37]. Римо-католицькі чернечі ордени належать до соціальних груп, які налаштовані проти загальноприйнятих у суспільстві нормативів культурного порядку і $\epsilon$ своєрідними «дублікатами» офіційних суспільних структур [3, с. 485].

На орденську структуру як органічну будову для об'єднання нації звертає увагу Д. Донцов. Він наголошує, що важливою рисою орденів $є$ їх ідеалізм, перевага якості над кількістю, безкомпромісність у досягненні мети. Метою орденів $є$ «радикальний переворот обставин і людської психіки», а програмою ордену - «цілий світогляд», «проголошення війни існуючому людові», існуючому світогляду. Але ідеєю орденів $є$ ідея активної меншості, яка провадить більшість [4].

Проблема значущості впливу західних духовних традицій на розвиток соціально-культурного середовища особливої актуальності 